\title{
Analysis of a unit management team's first year of business
}

\author{
ROGER MORGAN
}

Worcester and District Health Authority met various difficulties in its efforts to form a mental health services unit management team. The district contains two separate mental illness services, and the health authority decreed that these should form one unit thereby perpetuating the sector tier of management which the 1982 reorganisation was intended to abolish. The psychiatrists objected to this and wanted the district services at the Newtown branch of Worcester Royal Infirmary and at Powick Hospital (which together comprise the Worcester development project) to form one unit while the regional rehabilitation service at St Wulstan's Hospital formed another. The district enforced its decree and the resulting structure (three hospitals, two services, one unit) has caused recurring problems.

The first of these was linked with another district decree that the medical membership of each of its five unit management teams should consist of one hospital doctor and one general practitioner. It was tacitly accepted that Newtown would supply the one hospital doctor and there were objections by his two consultant colleagues to their exclusion from unit management in favour of a general practitioner for whose presence they could see no justification. The prospect for St Wulstan's was even bleaker if its management was to include medical representation by two doctors neither of whom was on its staff. After much delay and several acrimonious meetings and letters most of the doctors reluctantly agreed to a compromise. In return for accepting the general practitioner, Newtown and St Wulstan's would each have a medical representative. This left the Newtown consultants still feeling dissatisfied at being excluded and the non-medical unit management team members uneasy at the imbalance caused by having three doctors included.

This problem came to a head only after there had been considerable delay in appointing a director of nursing services, who did not take up his post until February 1983. The subsequent wrangling prevented formation of the team until April and it held its first meeting on 3 May. This paper analyses the business conducted by the unit management team in its first year of life from May 1983 to April 1984 inclusive.

\section{Method}

The analysis is based on the file in which I kept nearly all the papers relating to unit management team business. By the end of the year this file was 90 centimetres thick and weighed 3.75 $\mathrm{kg}$. The titles of the 247 minutes were listed in date order. Accompanying papers were assigned to the relevant minute and their pages were counted and noted. The source of each topic was recorded if known. Note was made of those topics that related either to the Newtown/Powick service or to the St Wulstan's service and whether specifically or generally. Finally, each minute topic was assigned to one of seven categories as follows:

St Wulstan's Hospital, Malvern, Worcs WR14 4JS

ROGER MORGAN, MB, MRCPSYCH, consultant psychiatrist
(1) Unit management team administration included programmes, agendas, minutes, and other administrative aspects of our meetings and business.

(2) Unit administration contained all non-clinical administrative matters including information and applications from within the unit.

(3) Planning initiated by the unit management team or initiated within the unit and accepted by the unit management team.

(4) Clinical items defined as matters affecting patients as people receiving treatment rather than as ordinary residents of any institution.

(5) Information received from outside the unit. This was all politely couched as information and ranged from the purely informative by infinite degrees through guidance and instructions to covert commands.

(6) Applications and requests received from outside the unit.

(7) Miscellaneous items not readily classifiable elsewhere.

\section{Results}

The unit management team met 22 times during the year and held one seminar with the three hospital management teams. The analysis is based on the records of these 23 meetings. I timed eight of them and believe these to be representative. Mean length was two hours 45 minutes ( $S D=25$ minutes). There were 122 attendances by members out of a possible 135 . The original five members of the team (unit administrator, who was chairman, director of nursing services, two consultants, and one general practitioner) were joined by a unit accountant after the third meeting.

Unit management team members also attended two seminars with the district health authority, one seminar with the district management team, and one meeting with the Newtown hospital management team, but no minutes were kept of these meetings so they have been omitted from the analysis. Estimates below of total times and costs of the meetings will therefore be underestimates.

The source of each minute item was known in $84 \%$ of cases and table I lists these together with the number of pages of handouts accompanying each. Of the 760 pages of paper,

TABLE I-Source of unit management team business $\times$ amount of paper

\begin{tabular}{lccc}
\hline & No of items & $\begin{array}{c}\text { Pages of } \\
\text { handout }\end{array}$ & $\begin{array}{c}\text { Mean No of } \\
\text { pages per item } \\
\text { (rounded) }\end{array}$ \\
\hline Deurce & 13 & & \\
$\begin{array}{l}\text { Security } \\
\text { Degional health authority }\end{array}$ & 6 & 90 & 7 \\
District & 47 & 44 & 6 \\
Social services & 9 & 36 & 4 \\
Unit management team member : & 47 & 114 & 2 \\
$\quad$ Administrator & 14 & 0 & 0 \\
Consultant & 6 & 0 & 0 \\
Nurse & 9 & 9 & 1 \\
Accountant & 26 & 60 & 2 \\
Agendas and minutes & 20 & 63 & 3 \\
Mental health unit & 10 & 21 & 1 \\
Nother sources & 40 & 48 & 3 \\
\hline Tot assignable & 247 & 760 & \\
\hline Total & & & \\
\hline
\end{tabular}


$54 \%$ rained down on us from above. Our masters were unable to say what they wanted to say to us in less than an average of six to seven pages an item. Lower levels of the hierarchy were progressively less verbose. (The amount of paper recorded as having been sent upwards from the mental health unit is spuriously high-duplicate copies of all the hospital management team minutes from the other hospitals reached me by two separate routes.)

A total of 568 man hours were spent on unit management team business. This included 122 attendances at meetings-average two and three quarter hours per meeting-335 hours; reading time- - two minutes a page $\times 760$ pages $\times$ six people -152 hours; and 81 hours travelling. This omits time spent by the unit administrator, accountant, and secretaries in preparing agendas and papers, producing minutes, etc. The total of 568 hours is the equivalent of 1440 -hour working weeks. In other words, each of the six members spent two and a half whole working weeks on attending these meetings.

Only $7 \%$ of the topics minuted concerned my own hospital specifically and a further $16 \%$ of topics concerned it along with the other hospitals. The total of $23 \%$ means that the balance of $77 \%$ of the topics did not concern me in any direct way.

Table II classifies the topics in different categories of business. The information and instructions from above again occupied

TABLE II-Topics of unit management team business

\begin{tabular}{|c|c|c|}
\hline & No of items & Pages of handout \\
\hline $\begin{array}{l}\text { Unit management team administration } \\
\text { Unit administration } \\
\text { Unit planning } \\
\text { Remotely clinical } \\
\text { Information received } \\
\text { Applications received from outside the } \\
\text { Miscellaneous }\end{array}$ & $\begin{array}{r}54 \\
59 \\
41 \\
9 \\
54 \\
18 \\
12\end{array}$ & $\begin{array}{r}99 \\
109 \\
171 \\
1 \\
351 \\
10 \\
19\end{array}$ \\
\hline Total & 247 & 760 \\
\hline
\end{tabular}

seven pages an item. Our own planning took four pages an item, but much of it had to be in a format dictated by the district which seemed quite unnecessarily long and elaborate. Our own administration required two pages an item and on the rare occasions when we became even remotely clinical little or no paper was needed.

When the year was divided into three four month periods and the results compared no consistent trends were apparent in any of the variables under analysis.

At current rates of pay (according to information kindly supplied by the unit accountant) team members received an aggregate of $£ 66.87$ an hour for their services. This means that each of our meetings cost about $£ 183$ and our activities over the whole year cost at least $£ 6330$.

\section{Discussion}

As a newcomer to this new style of management I am not yet brainwashed into accepting the need for so much time and paper. Surely there is a better way of using a consultant's time than to require him to set aside two and a half solid working weeks of every year amassing $3.75 \mathrm{~kg}$ of handouts when some $77 \%$ of both time and paper is irrelevant to his job. Yet to endure this is my only way of securing representation of my hospital within the existing structure and style of management.

The extent of irrelevance is equally striking if you examine the proportion of clinical content in the unit management team's deliberations (table II). Nine out of 247 items is less than $4 \%$ and six of the nine items were rather faintly clinical at bestthe possible transfer of a patient from Rampton, a discussion about occupational therapy recruitment and services, a reduction in the number of weekly electroconvulsive therapy sessions, a complaint about psychology services and arrangements for their external inspection, and notice of a visit from the Mental Health Act commissioners. The three other items considered the problem of managing violent and disturbed behaviour in one particular hospital: this was discussed by the unit management team only because that hospital's hospital management team was incapacitated at the time by a boycott by some of its essential members. To these nine clinical items could be added a further 13 items first classified under planning but retrieved on reanalysis because of a clinical element in their content. Together these 22 items amount to $9 \%$ of the unit management team's business. If the non-clinical component of management is rightly as high as $91 \%$ it is no wonder that few doctors have or retain enough interest and enthusiasm to spare time for it.

I see no obvious way of breaking this bureaucratic stranglehold now that Patients First has failed. Yet I remember with affection the far off days in the 1960s, pre-Salmon, prefunctional management and pre-1974, when our superb local administrators took pride in running slimline departments rather than building empires. They behaved as if their sole function was to enable clinical work to be done and they somehow contrived to use rather than stifle other people's initiative and enthusiasm. My hospital was treated as an entity instead of being submerged in a unit. Administration had to be and was devolved to the hospital secretary, who was a person of considerable rank and authority with the priceless advantage of exercising it on the spot. Doctor and nurse collaborated with him in tripartite management. They saw the group officers regularly and direct access was not only available but welcomed. They met their managers at two monthly house committee meetings and could state their case face to face with committee members the more alert of whom gradually built up an extensive knowledge of the hospital, its ethos, and its patients. No time was wasted on other people's business and the paper required weighed only two or three ounces a year. The good effects of this system filtered down to all staff and via them to the patients. All these good features have now been lost.

If I dare say a word of all this to younger colleagues they tell me to stop trying to turn the clock back. I do not see it quite like that, but I do wish that we could identify and preserve as many as possible of the good features of old ways and make progress forwards rather than backwards.

\section{Reference}

' Department of Health and Social Security. Patients First. London: HMSO, 1979. (Accepted 9 August 1984)

\section{THIRTY YEARS AGO}

Q.-For some years I have been paying my wife $£ 100$ per annum for secretarial and other assistance in the practice, claiming this amount as expenses in my income-tax returns. A new inspector of taxes regards this as my wife's salary and tells me I should have added it to my "income" each year. He has suggested making me pay on it for the last five years. If I paid the money to a secretary or maid I should not have to do this, so why should I have to in this case?

A.-Apparently the inspector of taxes does not object to the charging in the account of professional earnings of $£ 100$ as representing a reasonable payment for the wife's services to the practice, but claims that the $£ 100$ is part of the total joint income of the spouses and should be declared as such. If so, the inspector's contention is quite correct. So far as "income tax" is concerned the amount payable would not be affected-assuming that the wife has no other earned income-because it will be covered by the special allowance for the earned income of married women, but inclusion of the salary with other income would of course affect the total of the joint incomes on which surtax is payable. The fact that if the $£ 100$ had been paid to someone else it would not have been income of the wife is immaterial. The tax liability must be calculated on the basis of what the actual facts have been. (British Medical fournal 1954 ;ii:115). 


\section{Overseas doctors urged to play greater part in $\mathrm{HJSC}$}

The past chairman of the Hospital Junior Staff Committee, Mr Stephen Brearley, and the chairman of the junior doctors' forum of the Overseas Doctors Association, Dr Emile Morgan, have urged overseas doctors to play a greater part in the running of the HJSC and of regional committees. In a joint letter issued in the summer they stated:

"The Hospital Junior Staff Committee is the accredited representative body for all junior doctors working in the United Kingdom. Its membership includes doctors drawn from a wide range of grades and specialties throughout the country. It has, however, been a matter of concern that very few overseas graduates have been involved in the committee's work.

"During the past year one of us (ETM) has attended $\mathrm{HJSC}$ meetings as an observer from the junior members' forum of the Overseas Doctors Association. This has been enormously useful to both organisations. Although it is clear that British and overseas doctors each have specific problems, there are many more which are common to both.

"We therefore urge overseas doctors to involve themselves in the HJSC. Any doctor is welcome to attend meetings of regional hospital junior staff committees. These are normally advertised in hospital messes and further information can be obtained from
BMA regional offices. We hope that $\mathrm{RHJSCs}$ will elect a proportion of overseas doctors to serve on the national committee so that it can better represent the junior doctors of this country."

\section{Increase in fees}

\section{Central government departments}

Agreement has been reached with the Treasury for increases in fees payable by central government departments. The increases take effect from 1 April and 1 November 1984. The effects of the triennial review of these fees are not reflected in this agreement, but the BMA and the Treasury are working towards the implementation of changes agreed in the review with effect from 1 January 1985 . The fee for a chest $x$ ray examination goes up to $£ 21$ from 1 April and to $£ 22$ from 1 November the minimum fee for a consultant session goes up to $£ 55$ from 1 April and $£ 58$ from 1 November; and a member of a medical board will receive $f 42$ a session from 1 April and $£ 43$ from 1 November. BMA members may obtain full details from regional offices by quoting the reference "Fees 21" and their current membership number.

\section{Life assurance medicals}

The Life Offices Association and the BMA have agreed new fees for life assurance medicals from 1 November. The fee rises to $£ 20$ for a full medical and to $£ 10$ for a report without medical examination. The short form of medical report fee has been increased by $12^{\circ}$ " to $f 13$. Members should quote the reference "Fees 101."

\section{Deputising doctors}

The deputising doctors subcommittee of the private practice and professional fees committee has revised its recommended rates of pay for deputising doctors in accordance with the linkage to the average net remuneration of general practitioners agreed by the council and endorsed by the representative body. From 1 November the minimum for a six hour session rises to $£ 44 \cdot 10$ p or $£ 66 \cdot 15$ p for work between $11 \mathrm{pm}$ and $7 \mathrm{am}$; or $£ 5.51 \mathrm{p}$ an hour plus $£ 2.52$ a call for ordinary out of hours work, $£ 7.35$ an hour plus $£ 3.36$ a call at night, whichever is the greater.

\section{ASSOCIATION NOTICE}

\section{Change in title of division}

Notice is hereby given that, in future, the Ipswich Division will be known as the East Suffolk Division.

J D J Havard Secretary

\section{Elected representatives of BMA council 1984-5}

\section{ENGLAND BY REGION}

Northern: Dr George Cormack, general practitioner, Morpeth.

Yorkshire: Dr J M Dunlop, district medical officer, Kirkella, North Humberside.

Trent: Vacancy.

East Anglia: Dr A J Rowe, general practitioner, Bury St Edmunds.

North west Thames: Dr P F Kielty, general practitioner, Harpenden.

North east Thames: Dr Arnold Elliott, general practitioner, Ilford, Essex.

South east Thames: Dr W J Appleyard, consultant paediatrician, Canterbury.

South west Thames: Dr J S Horner, district medical officer, Croydon, Surrey.

Wessex: Mr Hugh Thelwall-Jones, consultant obstetrician and gynaecologist, Dorchester.

Oxford: Dr Serge Six, general practitioner, Reading.

South Western: Dr S Jane Richards, general practitioner, Exeter.

West Midlands: Dr Mary White, general surgery, Bromsgrove.

Mersey: Dr Mervyn Goodman, general practitioner, Liverpool.

North Western: Dr Simon Jenkins, general practitioner, Manchester.

\section{SCOTLAND}

Dr J A Ford, consultant paediatrician, Glasgow.
WALES

Dr G M Mitchell, senior lecturer, department of materia medica and pharmacology, Welsh National School of Medicine, Cardiff.

NORTHERN IRELAND

Mr Robert Gibson, consultant otolaryngologist, Belfast.

\section{ELECTED BY THE REPRESENTATIVE BODY}

Dr J G Ball, general practitioner, Bewdley, Worcs.

Mr D E Bolt, retired consultant surgeon, Honiton, Devon.

Mr R K Greenwood, consultant surgeon, Leicester.

Dr Samuel McKechnie, consultant anaesthetist, Wemyss Bay, Renfrewshire.

REPRESENTATIVES OF COMMITTEES ELECTED BY RB MEMBERS IN THE RELEVANT BRANCH OF PRACTICE

GMSC: Dr Peter Enoch, Dr Lionel Kopelowitz, Dr J S Noble, and Dr D E Pickersgill.

CCHMS: Dr J M Cundy and Dr E B Lewis.

HJSC: Dr Anne Blyth, Dr Timothy Fenton, and one vacancy.

CCCMCH: Dr Margaret Anderson.

The association's chief officers and the chairmen of standing committees are ex-officio members of the council. The chairmen and nominees of other committees are subject to reappointment. 